Article

\title{
Experimental Behavior of Cracked Reinforced Concrete Columns Strengthened with Reinforced Concrete Jacketing
}

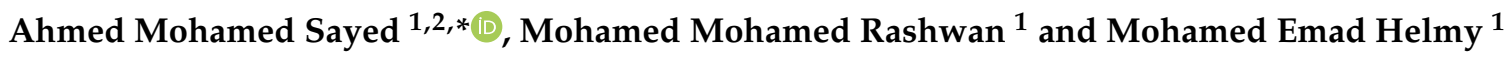 \\ 1 Department of Civil Engineering, College of Engineering, Assiut University, Assiut 71511, Egypt; \\ mohamed.rashwan@aun.edu.eg (M.M.R.); memad2661@gmail.com (M.E.H.) \\ 2 Department of Civil and Environmental Engineering, College of Engineering, Majmaah University, \\ Al-Majmaah 11952, Saudi Arabia \\ * Correspondence: a.sayed@mu.edu.sa
}

Received: 8 June 2020; Accepted: 22 June 2020; Published: 24 June 2020

\begin{abstract}
Reinforced concrete (RC) columns often need to be strengthened or rehabilitated to allow them to carry the loads applied to them. In previous studies, RC columns have been strengthened by jacketing, without considering the occurrence of cracking. In this study, the behavior of RC columns strengthened externally by jacketing after cracking is analyzed. The accuracy of the existing models was verified by analyzing the performance of fifteen RC columns with different cross-sections to determine the effect of new variables, such as the column size, amount of steel reinforcement, and whether the column was cracked or not, on the effectiveness of strengthening. The analysis demonstrated that this strengthening technique could effectively improve both the ductility and strength of RC column cross-sections. The results indicate that the model suggested by the ACI-318 code can predict the ultimate load capacity of RC columns without strengthening, or strengthened by RC jacketing before or after cracking, with higher accuracy and material efficiency. The RC columns without strengthening met the safety limit of the ACI-318 model. However, for strengthened columns, a reduction coefficient must be used to enable the columns to meet the safety limit, with values of $94 \%$ and $76 \%$ for columns strengthened before and after cracking, respectively. Furthermore, strengthening after cracking affects the ultimate load capacity of the column, with $15.7 \%, 14.1 \%$, and $13.5 \%$ lower loads for square, rectangular, and circular columns than those strengthened before cracking, respectively.
\end{abstract}

Keywords: RC column; RC jacketing; strengthening; column cracking; ACI-318 model

\section{Introduction}

Reinforced concrete (RC) columns must always be strengthened or rehabilitated to improve their efficiency in carrying the loads affecting them. The efficiency of columns in bearing loads can be affected by increases in the external loads, the generation of additional loads, such as seismic loads, or defects in the column due to mistakes in the design phase, the use of insufficient materials in the concrete mixing, or corrosion in the steel reinforcements of RC columns.

Many methods of strengthening RC columns have been developed. Older methods include the use of RC or steel angle jacketing, and modern methods include the use of different types of fiber-reinforced polymer jacketing. These methods can all increase the efficiency of RC columns by increasing their ultimate load capacity. Many previous studies have focused on strengthening RC columns under the influence of seismic loads by different methods [1-9]. Many studies have also studied the strengthening of RC columns under the influence of axial [10-26] or flexural [27-32] 
loads, or both [33-38]. Recently, a review was conducted that found that approximately 99 studies have been conducted on the strengthening of RC columns in the last twenty years [39]. The review was structured according to the method of strengthening, and indicated that none of these studies considered the effect of the presence of a preload or pre-cracks in the RC columns on the strengthening process. Some numerical studies considered the effect of preloading on strengthening with steel angle jacketing [40-42], and demonstrated that preloading greatly impacts the efficiency of the strengthening of RC columns according to the preload on the column. Therefore, in this study, RC columns were strengthened with RC jacketing after cracks formed on the sides of the columns, to determine their effect on the efficiency of strengthening.

Many of the current design models proposed by existing design codes $[43,44]$ or previous research $[23,45]$ can predict the ultimate load capacity with high accuracy, if there are no cracks or preloads on the RC columns. However, when cracks and preloads are present, these models require reduction factors to enable the design to fall within the safety limits [40].

The presence of preloads on the RC columns can cause cracking. Therefore, the strengthening process must at least consider the presence of loads that cannot be removed from the columns during the strengthening process. Consequently, in this study, an experimental test was conducted to assess the strengthening of columns by RC jacketing with different proportions of longitudinal steel reinforcements, to determine the effects of the presence of cracks in RC columns with different cross-sections on the efficiency of the strengthening process. The experimental results were compared to the existing design codes in order to determine their accuracy in such cases, as well as the values of the reduction factors required to allow the design to meet the safety limits.

The strengthening of RC columns, regardless of whether cracks have formed or not, aims to improve the strength, efficiency, and stiffness of RC columns, thereby maximizing their load capacity. Therefore, the purpose of this study—after reviewing previous research —is to address the shortcomings in the process of estimating the maximum axial load capacity of RC columns using RC jacketing after the appearance of cracks resulting from preloading. This study focuses on the influence of several variables that may have an impact on the efficiency of the strengthening process, such as the column size, amount of steel reinforcement, and whether the column is cracked or not. All of these variables aim to observe the extent to which these cracks affect the efficiency of the strengthening process. If there is a difference between the strengthening process of whether cracks have formed or not, the necessary reduction coefficient should be determined, which can be applied when using the current design codes.

\section{Experimental Tests}

\subsection{Specimen Details}

Fifteen RC columns with different cross-section shapes, divided into three groups, were tested under static loads. The first group consisted of five RC columns with a $200 \mathrm{~mm} \times 200 \mathrm{~mm}$ square cross-section and a total height of $1200 \mathrm{~mm}$. The second group consisted of five RC columns with a rectangular cross-section of $160 \mathrm{~mm} \times 250 \mathrm{~mm}$ and a total height of $950 \mathrm{~mm}$, and the third group consisted of five RC columns with a circular cross-section of $160 \mathrm{~mm}$ in diameter and a total height of $1200 \mathrm{~mm}$, as shown in Figure 1. A column from each group was tested until the point of failure and used as a control specimen. A load was then applied to the remaining columns of the group until the first crack appeared, following the approach described in Section 2.2, and the load application then ceased. The concrete compressive strength $f_{\mathrm{c}}{ }^{\prime}$ for each column is shown in Table 1 . Two types of steel bars were used to reinforce the RC columns, including deformed steel bars with diameters of $10 \mathrm{~mm}$ and $12 \mathrm{~mm}$, which were used for vertical reinforcement, and plain steel bars with a diameter of $8 \mathrm{~mm}$, which were used for stirrup reinforcement. All RC column stirrups had a diameter of $8 \mathrm{~mm}$ and spacing of $150 \mathrm{~mm}$, and had a yield and ultimate strengths of 327 and $457 \mathrm{MPa}$, respectively, as shown in Figure 1. The yield strengths of the bars with diameters of $10 \mathrm{~mm}$ and $12 \mathrm{~mm}$ were $411 \mathrm{MPa}$ and $441 \mathrm{MPa}$, and the ultimate strengths were $580 \mathrm{MPa}$ and $603 \mathrm{MPa}$, respectively. 


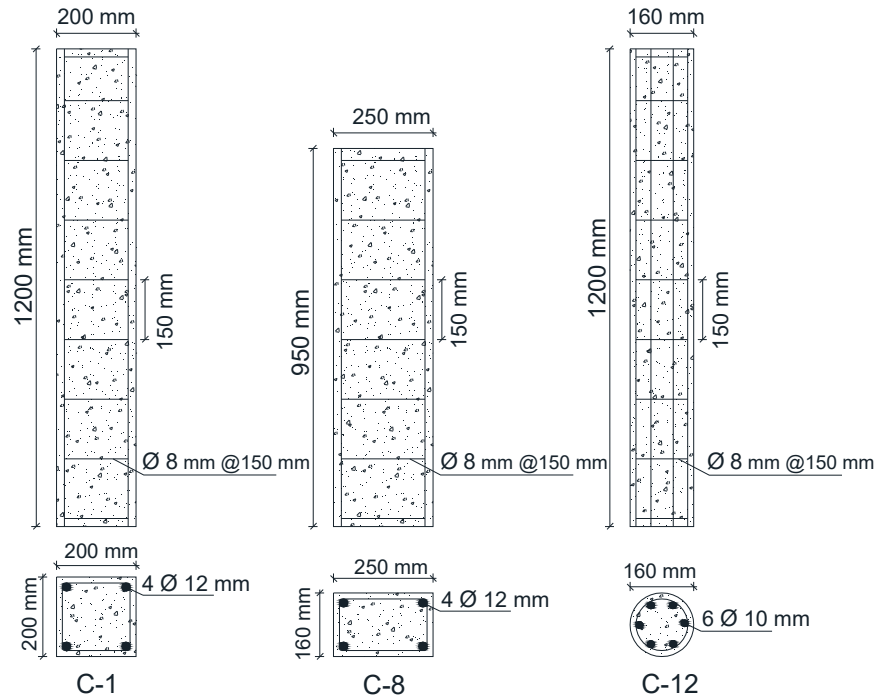

Figure 1. Geometric details of the RC columns.

Table 1. Properties of the reinforced concrete (RC) column specimens analyzed in this study.

\begin{tabular}{|c|c|c|c|c|c|c|c|}
\hline \multirow{2}{*}{ Column Shape } & \multirow{2}{*}{ Column Specimens } & \multicolumn{3}{|c|}{ Concrete Dimension (mm) } & \multirow{2}{*}{$A_{\mathrm{s}}$} & \multirow{2}{*}{$A_{\mathrm{s}} / A_{\mathrm{c}}$} & \multirow{2}{*}{$\begin{array}{l}\text { Concrete } \\
f_{c}^{\prime}(\mathbf{M P a})\end{array}$} \\
\hline & & $b$ & $t$ & $h$ & & & \\
\hline Square & $C-1,5,6,7$ and 16 & 200 & 200 & 1200 & $4 \varnothing 12$ & $1.13 \%$ & 25.5 \\
\hline Rectangular & $\mathrm{C}-8,9,10,11$ and 17 & 160 & 250 & 950 & $4 \varnothing 12$ & $1.13 \%$ & 22.7 \\
\hline Circular & C- $-12,13,14,15$ and 18 & \multicolumn{2}{|c|}{160 Diameter } & 1200 & $6 \varnothing 10$ & $2.34 \%$ & 22.1 \\
\hline
\end{tabular}

The three specimens that were tested until the point of the first crack were strengthened by complete reinforced concrete jacketing. This involved increasing the concrete cross-section dimensions for each side of the square and rectangular columns by $100 \mathrm{~mm}$, as shown in Figure 2, and increasing the diameter of the circular column by $100 \mathrm{~mm}$, as shown in Figure 3 . The compressive strengths $f_{\mathrm{c}}{ }^{\prime}$ of the concrete jacketing and steel reinforcements used to strengthen each column are listed in Table 2.

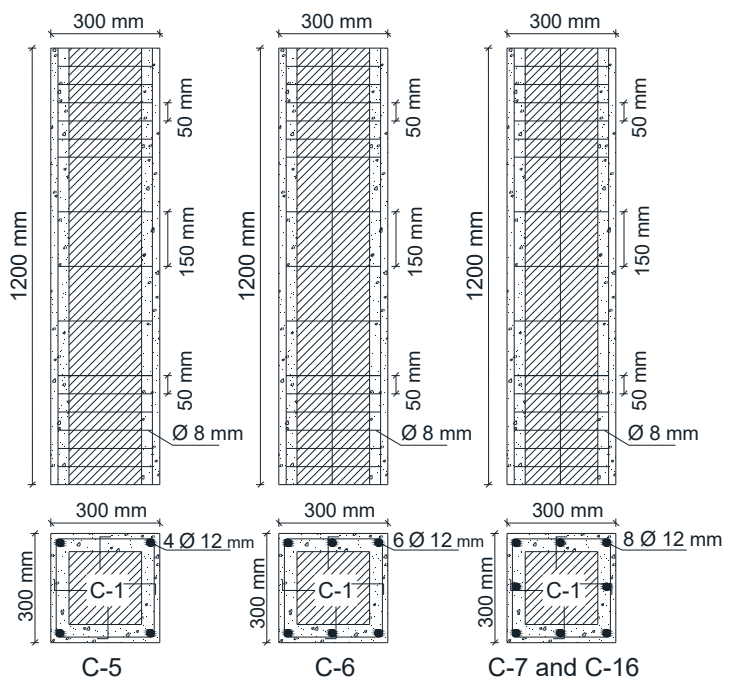

(a) Square RC columns
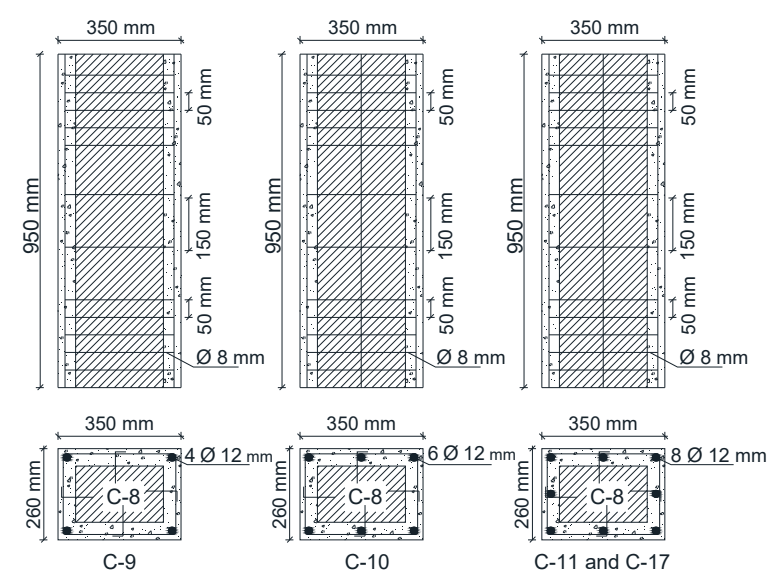

(b) Rectangular RC columns

Figure 2. Details of the RC columns strengthened by complete RC jacketing.

The strengthening process is carried out in several steps: First, the external surfaces of all the columns that are to be strengthened are cleaned and have their surfaces roughened by removing the 
outer concrete cover and any unstable concrete parts that have resulted from cracks. Second, the holes that are made in the sides of the column's perimeter with a depth of $50 \mathrm{~mm}$ and a diameter of $8 \mathrm{~mm}$ are distributed on the sides of the column's cross-section, as shown in Figures 2 and 3. Then, the anchorage bolts are placed in the form of an L-shape with a total length of $90 \mathrm{~mm}$ and a diameter of $5 \mathrm{~mm}$, and are fixed inside these holes using Kemapoxy adhesive material 165. Third, new stirrups are added with a diameter of $8 \mathrm{~mm}$ with the distribution, shown in Figures 2 and 3, and they are connected to the pre-fixed anchorage bolts, then added to the new vertical steel reinforcement inside these stirrups. Finally, new concrete is cast to be the external strengthening of the columns.

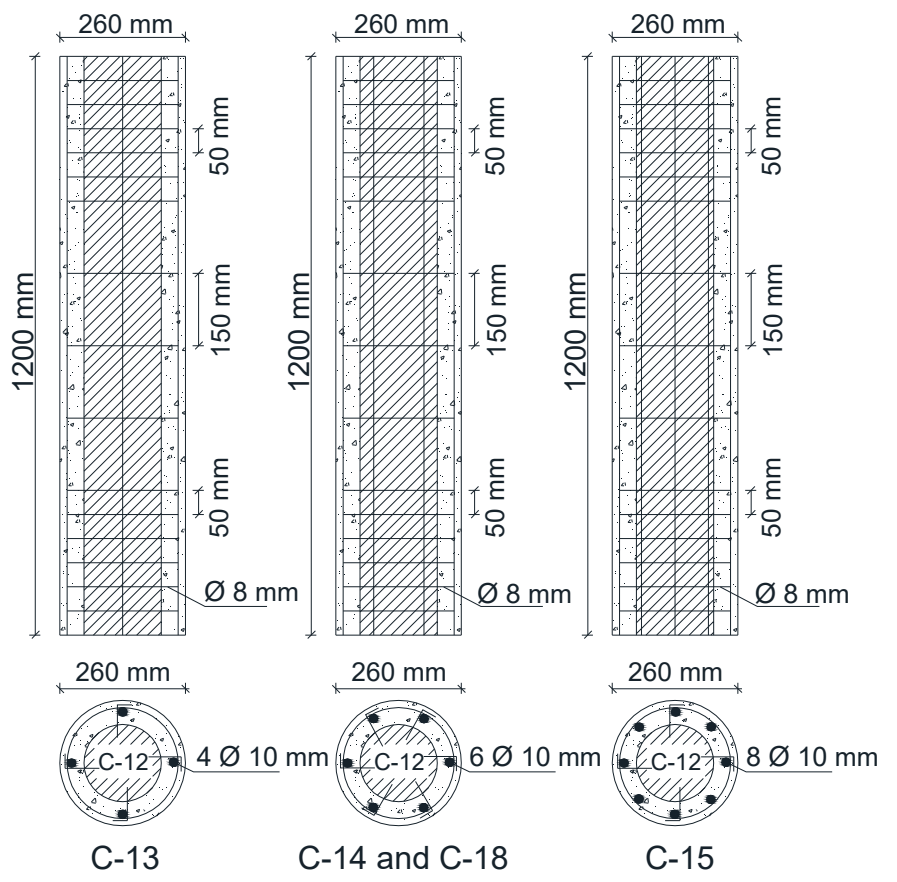

Figure 3. Details of the circular RC columns strengthened by complete RC jacketing.

Table 2. Properties of the RC column specimens strengthened by complete RC jacketing.

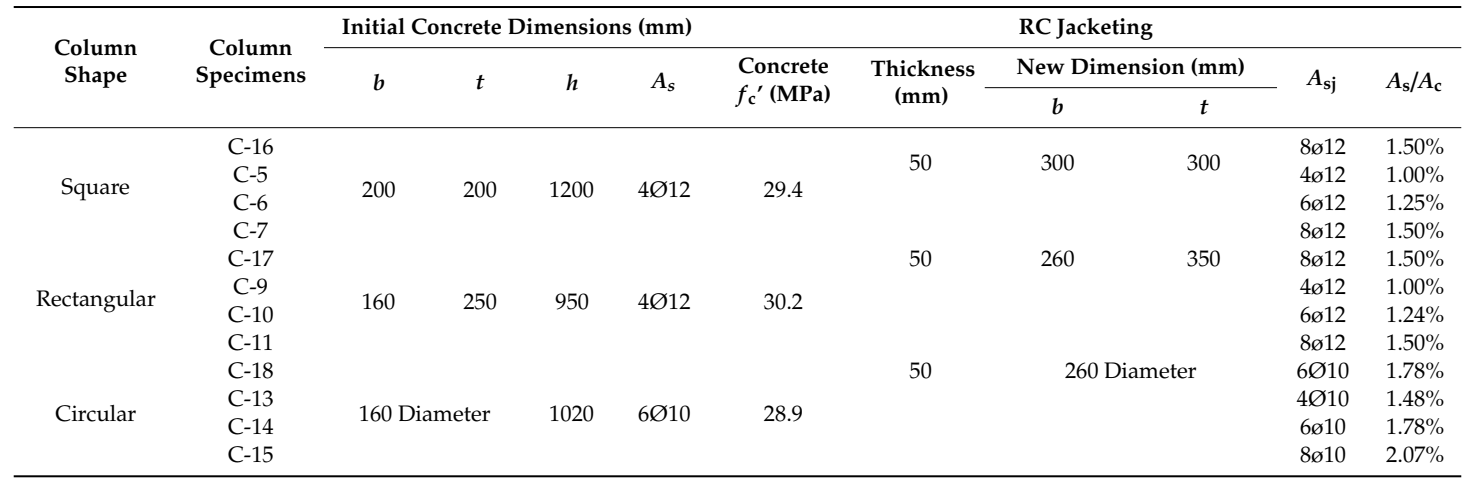

\subsection{Instrumentation and Test Setup}

All of the RC columns were tested using a loading machine (Civil Engineering Department Lab, Assiut University, Assiut, Egypt) with a capacity of $5000 \mathrm{kN}$. The testing machine had upper and lower heads. The upper head could be fixed at any height according to the column length, while the lower head only moves upward when loading. A computer-aided data acquisition system was used to monitor the load, displacements, and strains throughout the loading tests at selected time intervals. The vertical displacement was measured to monitor the axial shortening of each column and the horizontal displacement of the column at mid-height; the strain on the vertical steel reinforcement, 
and the horizontal strain on the concrete surface at the mid column height were also measured. Electrical resistance strain gauges were attached to the steel reinforcements and concrete surfaces to measure the strain of the steel reinforcements and concrete. The displacement was measured using linear variable displacement transducers (LVDTs).

\section{Results and Discussion}

\subsection{Crack Patterns and the Axial Load Capacity of Control Columns}

The first cracks in the control columns (C-1, C-8, and C-12) were observed at the bottoms and tops of the columns at loads of $562 \mathrm{kN}, 502 \mathrm{kN}$, and $318 \mathrm{kN}$, respectively. By increasing the applied load, the cracking increased and the final failure location was observed at the top of the column height, as shown in Figure 4. The control RC column test specimens failed at applied loads of $1229 \mathrm{kN}, 1073 \mathrm{kN}$, and $635 \mathrm{kN}$, respectively.

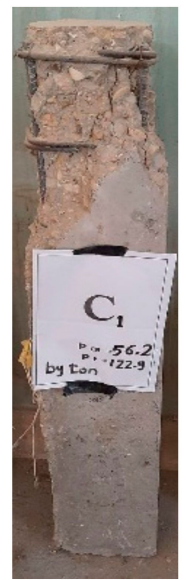

(a) C-1

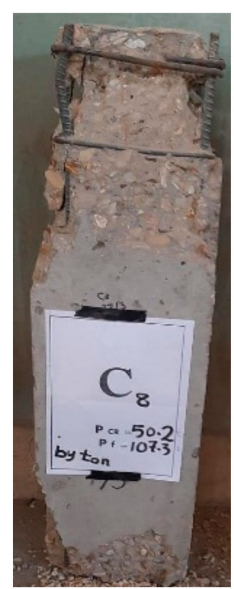

(b) C-8

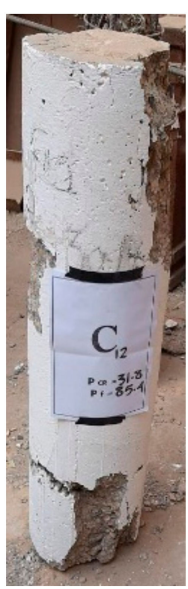

(c) $\mathrm{C}-12$

Figure 4. Crack patterns of the control RC columns without strengthening.

For the RC columns strengthened by complete RC jacketing, the first cracks were observed at the bottoms and tops of the columns, as shown in Figure 5. After reaching the first crack load, the load was stopped until the column was set for strengthening. Table 3 shows the cracking and ultimate load capacities of the control RC columns without strengthening, the RC columns strengthened without pre-cracking, and the RC columns that will be strengthened by complete RC jacketing after cracking.

Table 3. Summary of the experimental test results.

\begin{tabular}{cccc}
\hline Column Shape & Column Specimen & Cracking Load (kN) & Ultimate Load (kN) \\
\hline \multirow{4}{*}{ Square } & C-1 & 562 & 1229 \\
& C-16 & 1445 & 2883 \\
& C-5 & 550 & - \\
& C-6 & 588 & - \\
C-7 & 541 & 1073 \\
Rectangular & C-8 & 502 & 2822 \\
& C-17 & 1425 & - \\
& C-9 & 541 & - \\
& C-10 & 499 & - \\
& C-11 & 471 & 635 \\
& C-12 & 318 & 1709 \\
Circular & C-18 & 854 & - \\
& C-13 & 263 & - \\
& C-14 & 277 & - \\
\hline
\end{tabular}




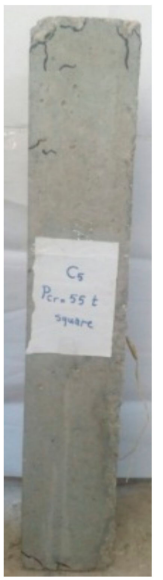

C-5

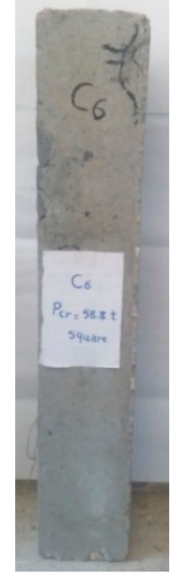

C-6

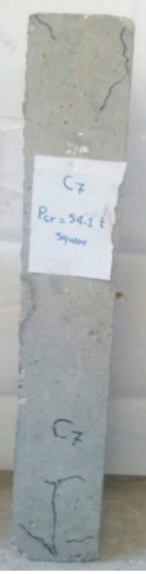

C-7

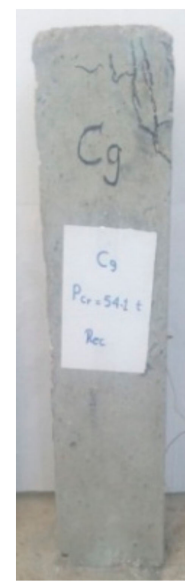

C-9

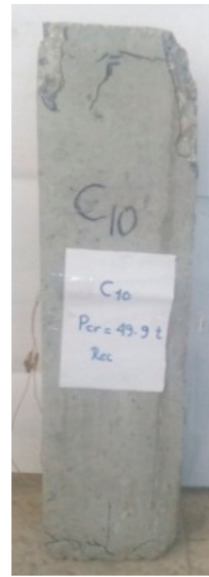

C-10

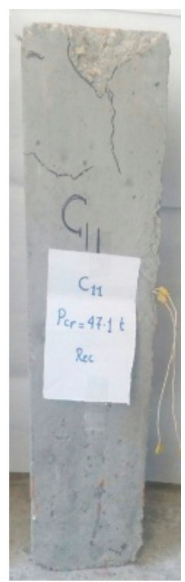

C-11

(a) Square RC columns

(b) Rectangular RC columns

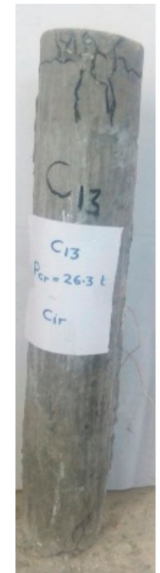

C-13

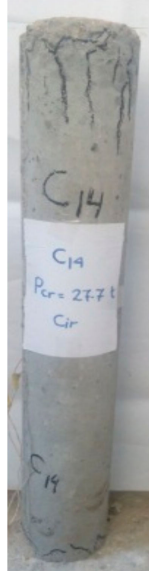

C-14

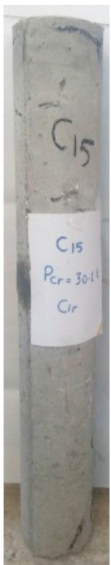

C-15

(c) Circular RC columns

Figure 5. Crack patterns of the RC columns without strengthening.

\subsection{Crack Patterns and the Failure Loads of the Strengthened Columns}

Two types of strengthening were tested, i.e., strengthening after cracking (C-5, C-6, and C-7) and strengthening before cracking (C-16). The shapes of the cracks and the failure in almost all columns were similar. A major vertical crack parallel to the axis of the column was observed and identified as the reason for the failure of the square RC columns, as shown in Figure 6.

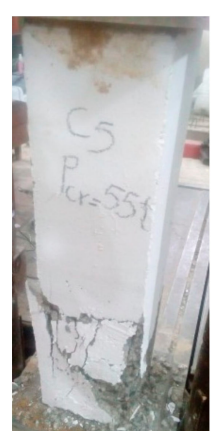

(a) C-5

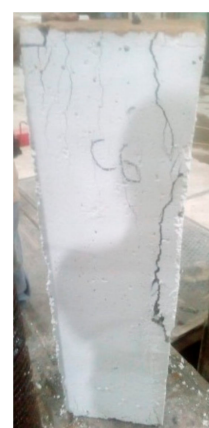

(b) C-6

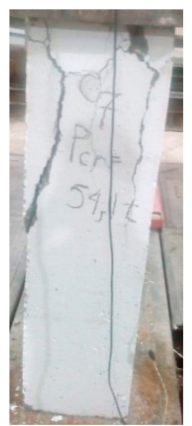

(c) C-7

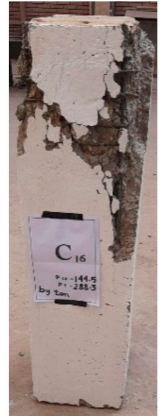

(d) C-16

Figure 6. Crack patterns of the strengthened square RC columns. 
Furthermore, for the rectangular and circular columns that were strengthened before and after cracking, the shape of the failure was identical to that of the square columns, as shown in Figure 7.

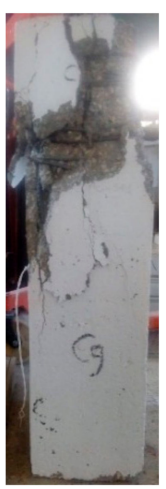

C-9

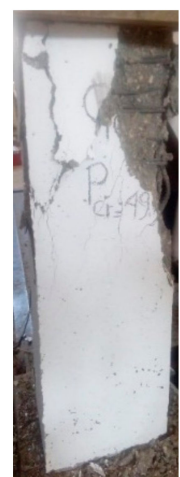

C-10

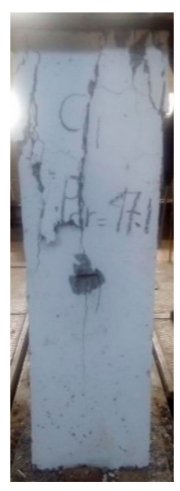

C-11

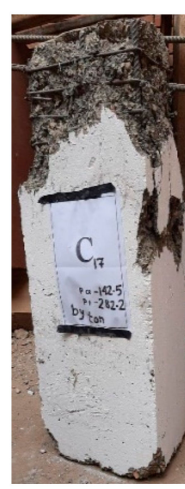

C-17

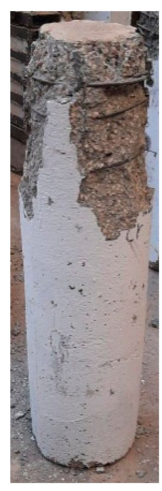

C-13

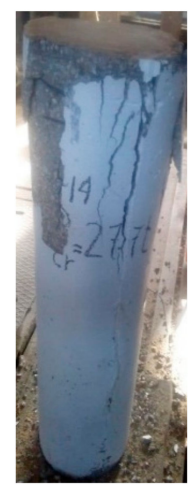

C-14

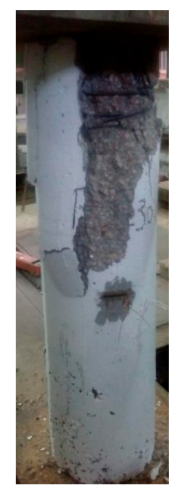

C-15

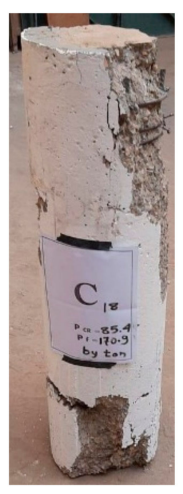

C-18

(a) Rectangular RC columns

(b) Circular RC columns

Figure 7. Crack patterns of the strengthened RC columns.

The ultimate load of all of the columns was determined from the measured variables, as shown in Table 4 . The table indicates that the columns without strengthening exhibited the lowest ultimate load values, and the columns strengthened without cracks exhibited the highest load values. The load values of the columns strengthened after cracking were between these. Furthermore, the efficiency of the strengthening process for the rectangular columns was better than that for the square columns, as the percentage increase in the failure load of the rectangular columns after strengthening was greater than that in the square columns with the same cross-sectional area and strengthening process. Furthermore, the axial load capacity of the columns that strengthened after cracking were lower than those of the columns strengthened before cracking, and these deficiencies changed with the shape of the column cross-section, with decreases of $15.7 \%, 14.1 \%$, and $13.5 \%$ for the columns with square, rectangular, and circular cross-sections under the same strengthening conditions, respectively.

Table 4. Summary of RC columns strengthened by RC jacketing.

\begin{tabular}{ccccc}
\hline Column Shape & Column Specimen & Ultimate Load $\mathbf{( k N )}$ & \% Increase & \% Decrease \\
\hline \multirow{5}{*}{ Square } & C-1 & 1229 & --- & --- \\
& C-16 & 2883 & 134.5 & --- \\
& C-5 & 2225 & 81.0 & --- \\
& C-6 & 2253 & 83.3 & -- \\
Rectangular & C-7 & 2430 & 97.7 & 15.7 \\
& C-8 & 1073 & --- & -- \\
& C-17 & 2822 & 163.0 & -- \\
& C-9 & 2155 & 100.8 & -- \\
& C-10 & 2324 & 116.6 & -- \\
& C-11 & 2423 & 125.8 & 14.1 \\
Circular & C-12 & 635 & --- & -- \\
& C-18 & 1709 & 169.1 & -- \\
& C-13 & 1411 & 122.2 & 13.5 \\
\hline
\end{tabular}

$\%$ Increase $=$ percentage of increase in the failure load from the $\mathrm{RC}$ column without strengthening. $\%$ Decrease $=$ percentage of decrease in the failure load from the RC column strengthened before cracking.

\subsection{Load-Displacement Relationships}

The vertical displacement of the columns when a load was applied until the point of failure was measured, as shown in Figure 8. These Figures indicate that the strengthened columns exhibited greater 
displacement than the strengthened columns at the same applied load, and that the efficiency of the columns strengthened before cracking was greater than that of the columns strengthened after cracking. This is evident from the angle of inclination of the curves. The inclination of the curves also indicates the differences between the columns with different cross-sections. The vertical displacement values were close for all columns, regardless of whether they were strengthened, as these values correspond to the maximum strain of concrete and the yield strain of the main vertical steel reinforcement.

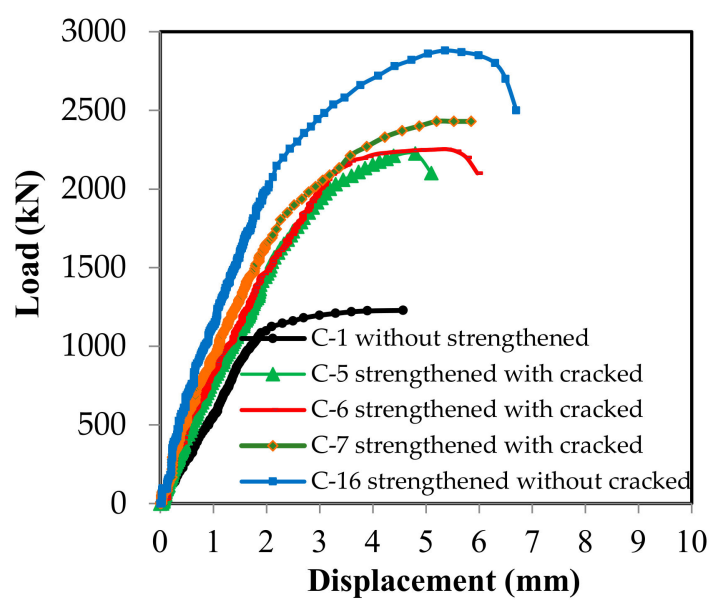

(a) Square RC columns

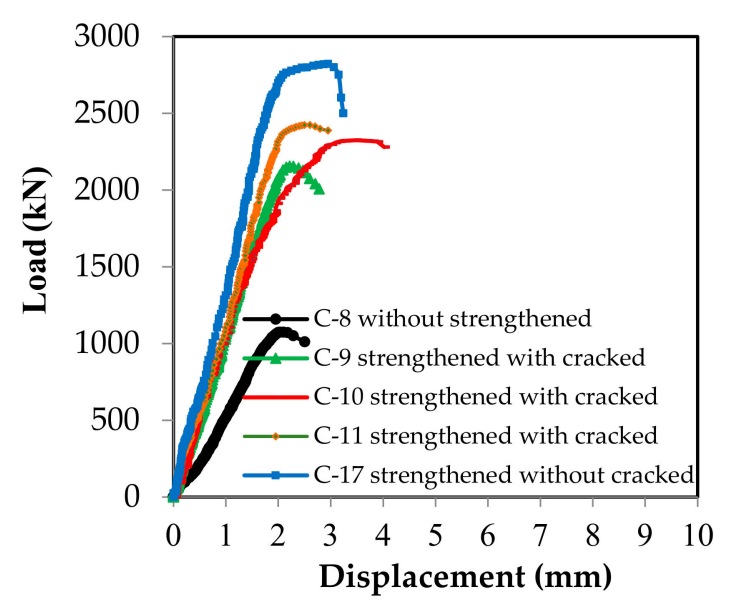

(b) Rectangular RC columns

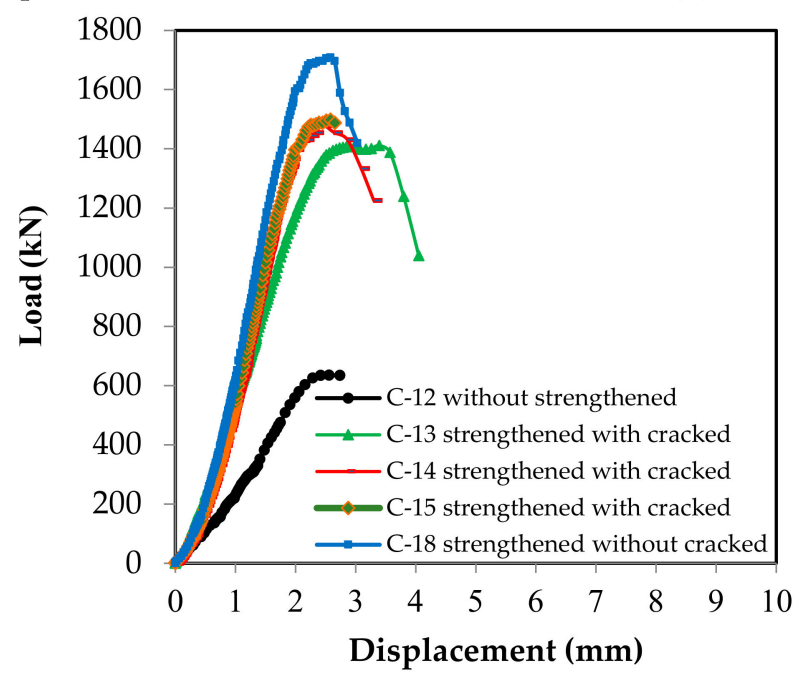

(c) Circular RC columns

Figure 8. Load-displacement relationships for the RC columns.

\subsection{Effect of Longitudinal Steel Reinforcement in RC Jacketing}

Figure 9 indicates that the effect of the longitudinal steel reinforcement in the RC jacketing is very similar among all of the RC column cross-section shapes, where the correlation coefficients are 0.97, 0.99, and 0.97 for the square, rectangular, and circular RC columns, respectively. This result corresponds to the existing models, which calculate the steel reinforcement effect without any reduction coefficients. That is, the effect of longitudinal reinforcement is linear when increasing the ultimate load capacity of the RC columns.

Figure 10 also indicates that the relationship between the strains and loads for longitudinal steel is almost linear, and this is consistent with the result shown in Figure 9. Although the strain values decreased as the ratio of the longitudinal steel reinforcement in the RC column increased under the same load level, the maximum strain value for all of the RC columns with different ratios of longitudinal 
steel reinforcement reached the final yield stage of the steel material, and the failure of the RC column subsequently occurred. This is consistent with the current design models.

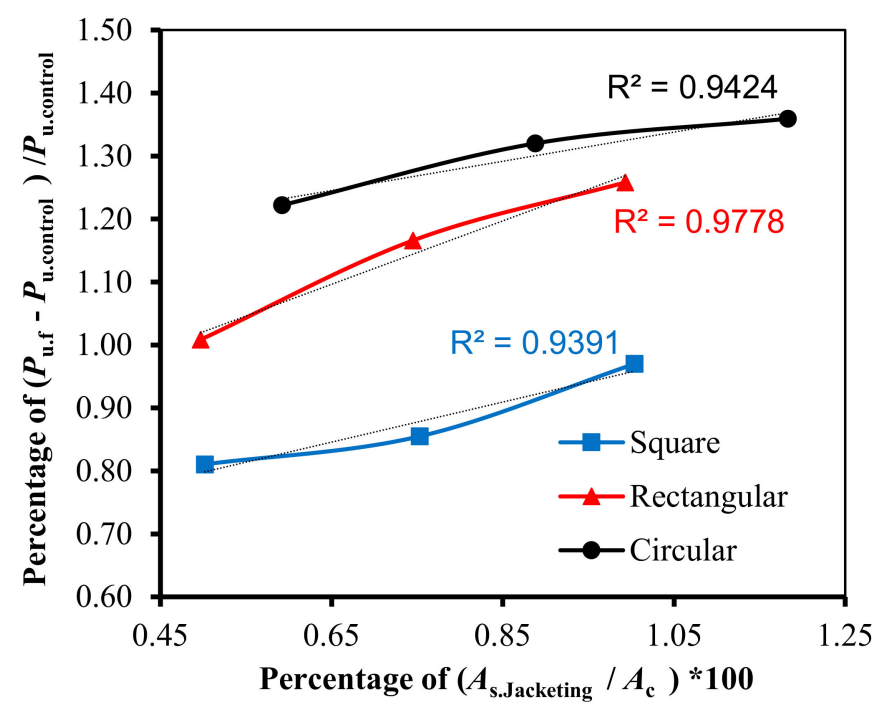

Figure 9. The relationship between the percentage of increase in column capacity and the percentage of longitudinal reinforcement in RC jacketing for different column cross-section shapes.

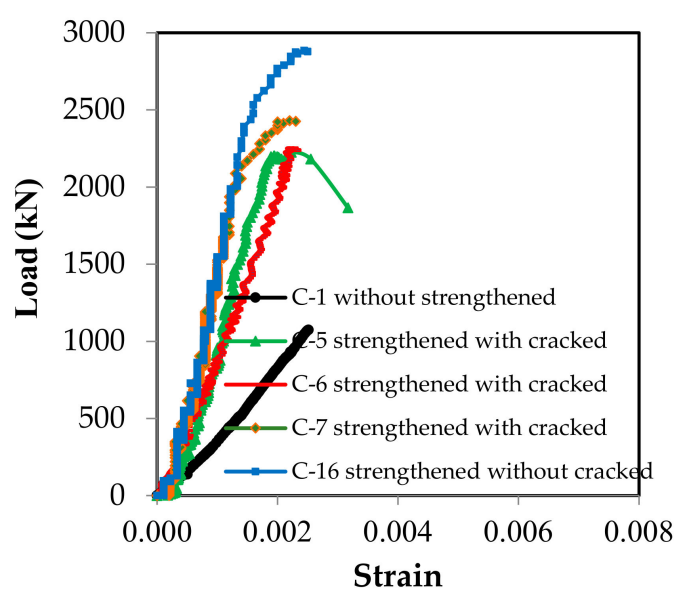

(a) Square RC columns

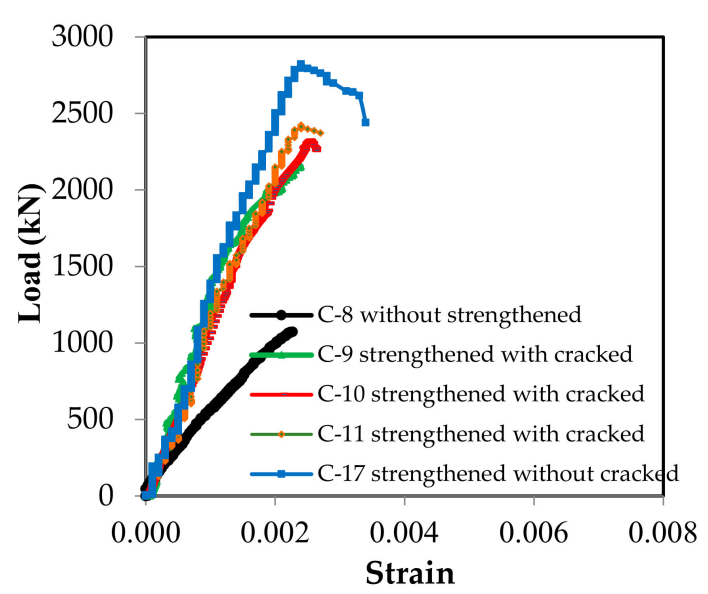

(b) Rectangular RC columns

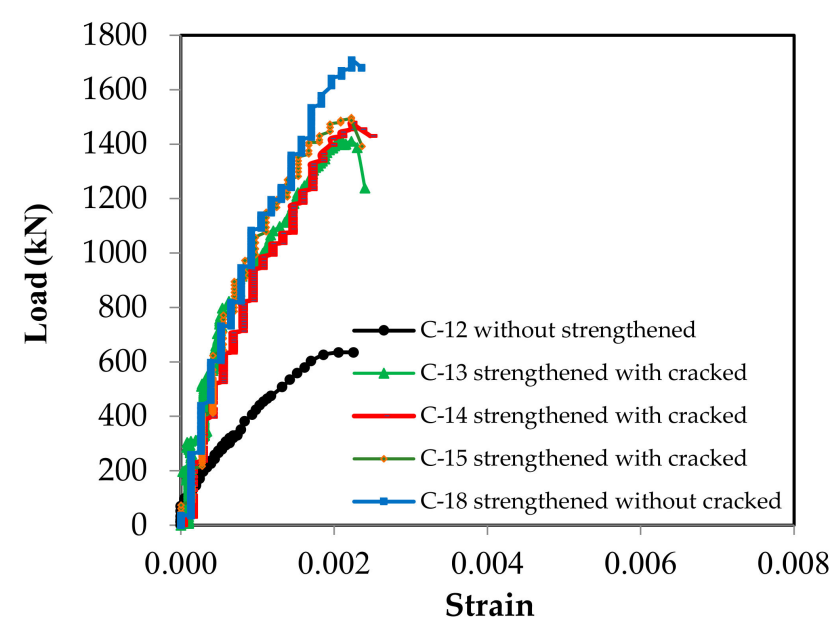

(c) Circular RC columns

Figure 10. Load-longitudinal steel strain relationships for the RC columns. 


\section{Comparison of the Results with the Existing Design Models}

One of the most important design equations used in calculating RC column capacity is the ACI-318 code model [43], as it is the basic equation for all existing design models. The model proposed by the ACI-318 code [43] is used for the RC columns that are not strengthened or have been strengthened by $\mathrm{RC}$ jacketing, and gives the designed axial load capacity of the RC columns, as shown in Equation (1).

$$
\phi P_{n, \max }=0.80 \phi\left[0.85 f_{\mathcal{c}}^{\prime}\left(A_{g}-A_{s t}\right)+\left(f_{y} A_{s t}\right)\right]
$$

Equation (1) contains more than one safety factor to reduce the load from the failure load to the design load, i.e., $\phi, 0.85 f^{\circ}$ and 0.80 . If these factors are omitted, a model for calculating the ultimate axial load capacity for the RC column is obtained.

$$
P_{u . f}=f_{c}^{\prime}\left(A_{c}-A_{s t}\right)+\left(f_{y} A_{s t}\right)
$$

Table 5 indicates the value expected by the ACI-318 code [43], and the ratio between this value and the experimental ultimate load values, for all columns. This is also graphically represented in Figure 11. The results indicate that the prediction of the ACI-318 code model [43] in the RC columns without strengthening was highly accurate, where the average ratio of $P_{u \text {.Ex }} / P_{\mathrm{u} . \mathrm{ACI}}$ was 1.00 , with a coefficient of variation of $2.12 \%$ and a correlation coefficient of 0.997 . The average ratio of $P_{\mathrm{u} \text {.Ex }} / P_{\mathrm{u} \text {.ACI }}$ for the load prediction for the strengthened RC columns without cracks was 0.95 , the coefficient of variation was $1.82 \%$, and the correlation coefficient was 0.998 . However, the prediction values exceeded the experimental test results, and they were outside the safety limits. For the RC columns strengthened after the cracks occurred, the average ratio of $P_{\mathrm{u} \text {.Ex }} / P_{\mathrm{u} \text {.ACI }}$ was 0.80 , the coefficient of variation was $3.51 \%$, and the correlation coefficient was 0.994 . However, all values for these columns were in the unsafe region of the predicted failure loads, as shown in Figure 11. The load predicted using the ACI-318 [43] equation should be reduced to a ratio of at least $80 \%$, and it is preferable that the lowest ratio that was observed in the analysis process of $76 \%$ be taken to ensure that all values are within the limits of safe design.

Table 5. Summary of the loads of the RC columns strengthened with RC jacketing and predicted using the ACI-318 code [43].

\begin{tabular}{ccccc}
\hline Column Shape & Column Specimen & Ultimate Load $\mathbf{k N})$ & $\boldsymbol{P}_{\text {u.f. }}$ ACI-318 (kN) & Ratio of $\boldsymbol{P}_{\mathbf{u} . \text { Ex }} / \boldsymbol{P}_{\mathbf{u} . \text { ACI }}$ \\
\hline \multirow{5}{*}{ Square } & C-1 & 1229 & 1208 & 1.02 \\
& C-16 & 2883 & 3050 & 0.95 \\
& C-5 & 2225 & 2864 & 0.78 \\
& C-6 & 2253 & 2957 & 0.76 \\
C-7 & 2430 & 3050 & 0.80 \\
Rectangular & C-8 & 1073 & 1097 & 0.98 \\
& C-17 & 2822 & 3009 & 0.94 \\
& C-10 & 2155 & 2823 & 0.76 \\
& C-11 & 2324 & 2916 & 0.80 \\
& C-12 & 2423 & 3009 & 0.81 \\
Circular & C-18 & 635 & 628 & 1.01 \\
& C-13 & 1709 & 1761 & 0.97 \\
& C-14 & 1411 & 1701 & 0.83 \\
& C-15 & 1479 & 1761 & 0.84 \\
\end{tabular}

Table 5 also shows the deficiencies between the test results and the values predicted by the ACI-318 model [43] due to the type of strengthening. Deficiencies were observed for strengthening before cracking as there were two grades of concrete in the column, as the core of the column was weak, and the RC jacketing was strong, resulting in differences in the strains of the contact surfaces between the column and reinforcement. This affected the ultimate capacity of the column, and the average 
ratio decreased to $5 \%$. For strengthening after cracking, the deficiency was the result of two factors. One factor was the difference in strains between the concrete in the core of the column and the concrete used for strengthening. The second is the presence of cracks in the core of the column, which affected the efficiency of the strengthening and the ultimate capacity of the column. The average percentage of deficiency reached $20 \%$.

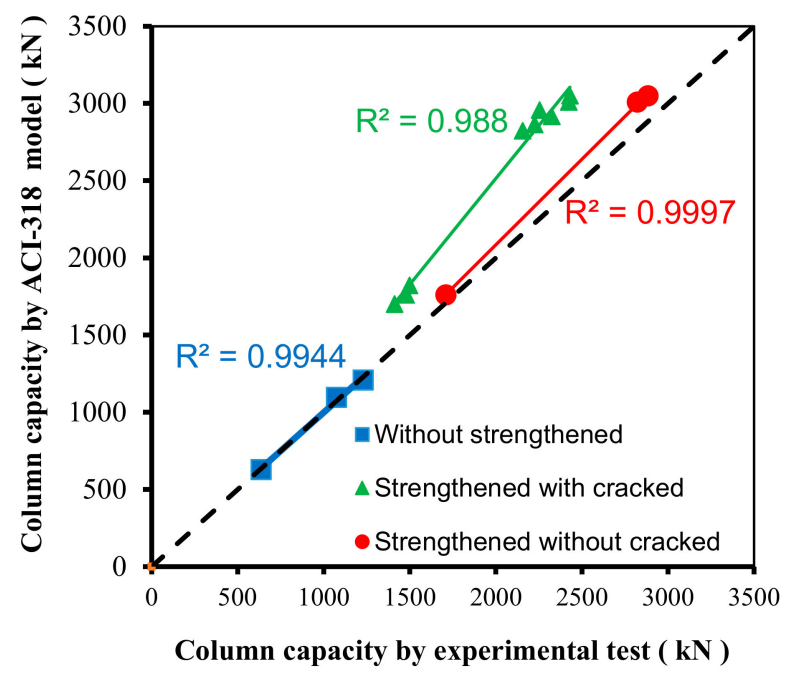

Figure 11. Comparison between the ACI-318 model [43] and the experimental test results.

\section{Conclusions}

RC columns are commonly strengthened by RC jacketing; however, all previous studies and models used to calculate the ultimate load capacity of these columns were conducted on columns that did not contain cracks before strengthening. Therefore, the main objective of this research was to determine the efficiency of the strengthening of such columns after crack formation. The results were compared to the model available in the ACI-318 code [43] in order to determine the accuracy of its use in such cases. From the analysis of the results, some conclusions were drawn, as follows:

- $\quad$ The presence of cracks before strengthening affects the maximum load capacity of RC columns. The capacities of square, rectangular, and circular RC columns strengthened after cracking were $15.7 \%, 14.1 \%$, and $13.5 \%$ lower than those of columns strengthened before cracking, respectively.

- The ACI-318 model [43] can predict the ultimate load capacity with higher accuracy and higher material efficiency. However, it requires reduction factors of up to 0.94 and 0.76 when applied to columns strengthened without and with cracks, before all RC columns are considered safe, respectively.

- The effect of the ratio of vertical steel reinforcement in the RC jacketing on the ultimate load capacity of the RC columns is linear.

- The effect of the vertical steel reinforcement ratio in the $\mathrm{RC}$ jacketing on the ultimate load capacity of the RC column is linear, regardless of whether the column was strengthened before or after cracking.

Future research could focus on the study of strengthening RC columns after cracks that occur under the effect of preloading using other types of strengthening operations, such as the use of fiber-reinforced polymer (FRP) composite or the use of steel angle jacketing, which does not receive considerable attention in the literature. All of these new research findings guide the current code to complete the existing design gaps.

Author Contributions: Conceptualization, A.M.S. and M.M.R.; methodology, A.M.S., M.M.R. and M.E.H.; software, A.M.S., and M.M.R.; validation, A.M.S., M.M.R. and and M.E.H.; formal analysis, A.M.S., and M.M.R.; investigation, A.M.S., M.M.R., and M.E.H.; resources, A.M.S., M.M.R., and M.E.H.; data curation, A.M.S.; 
writing—original draft preparation, A.M.S., and M.E.H.; writing—review and editing, A.M.S., and M.M.R..; visualization, A.M.S.; supervision, A.M.S., and M.M.R.; project administration, A.M.S., and M.M.R.; funding acquisition, A.M.S., and M.M.R.All authors have read and agreed to the published version of the manuscript.

Funding: This research received no external funding.

Acknowledgments: The Deanship of Scientific Research, Majmaah University, deserves special thanks for his generous support for the accomplishment of this task under Project Number No. 1439-46.

Conflicts of Interest: The author declares no conflict of interest.

\section{Abbreviations}

The following abbreviations are used in this manuscript:

$A_{c} \quad$ The concrete cross-section area

$A_{g} \quad$ The concrete cross-section area inside the stirrups

$A_{S} \quad$ The total longitudinal steel reinforcement cross-section

$A_{\text {st }} \quad$ The steel reinforcement cross-section

$A_{s j} \quad$ The cross-section area of steel reinforcement in RC jacketing

$f_{c}{ }^{\prime} \quad$ The concrete compressive strength

$f_{y} \quad$ The longitudinal steel yield strength

$P_{n . \max } \quad$ The design axial load capacity of the RC column

$P_{u . E x} \quad$ The experimental ultimate axial load capacity of the RC column

$P_{u . A C I} \quad$ The ultimate axial load capacity of the RC column from the ACI-318 model

$\phi \quad$ The capacity safety factor

\section{References}

1. Vandoros, K.G.; Dritsos, S.E. Concrete jacket construction detail effectiveness when strengthening RC columns. Constr. Build. Mater. 2008, 22, 264-276. [CrossRef]

2. Chang, S.Y.; Chen, T.W.; Tran, N.C.; Liao, W.I. Seismic retrofitting of RC columns with RC jackets and wing walls with different structural details. Earthq. Eng. Vib. 2014, 13, 279-292. [CrossRef]

3. Liu, C.Y.; Ma, H.; Chen, L.; Li, Z.B.; Yang, D.B. Experimental study on seismic performance of reinforced concrete column retrofitted by asymmetric increased single lateral section. Adv. Struct. Eng. 2017, 20, 1325-1339. [CrossRef]

4. Ou, Y.C.; Truong, A.N. Cyclic behavior of reinforced concrete L-and T-columns retrofitted from rectangular columns. Eng. Struct. 2018, 177, 147-159. [CrossRef]

5. Deng, M.K.; Zhang, Y.X.; Li, Q.Q. Shear strengthening of RC short columns with ECC jacket: Cyclic behavior tests. Eng. Struct. 2018, 160, 535-545. [CrossRef]

6. Choi, E.; Chung, Y.S.; Park, C.; Kim, D.J. Seismic performance of circular RC columns retrofitted with prefabricated steel wrapping jackets. Mag. Concr. Res. 2013, 65, 1429-1440. [CrossRef]

7. Wang, L.; Su, R.K.L.; Cheng, B.; Li, L.Z.; Wan, L.; Shan, Z.W. Seismic behavior of preloaded rectangular RC columns strengthened with precambered steel plates under high axial load ratios. Eng. Struct. 2017, 152, 683-697. [CrossRef]

8. Colomb, F.; Tobbi, H.; Ferrier, E.; Hamelin, P. Seismic retrofit of reinforced concrete short columns by CFRP materials. Compos. Struct. 2008, 82, 475-487. [CrossRef]

9. Ozcan, O.; Binici, B.; Ozcebe, G. Seismic strengthening of rectangular reinforced concrete columns using fibre reinforced polymers. Eng. Struct. 2010, 32, 964-973. [CrossRef]

10. Meda, A.; Mostosi, S.; Rinaldi, Z.; Riva, P. Corroded RC columns repair and strengthening with high performance fibre reinforced concrete jacket. Mater. Struct. 2016, 49, 1967-1978. [CrossRef]

11. Abdullah, A.; Takiguchi, K. An investigation into the behavior and strength of reinforced concrete columns strengthened with ferrocement jackets. Cem. Concr. Compos. 2003, 25, 233-242. [CrossRef]

12. Ma, R.; Xiao, Y.; Li, K.N. Full-scale testing of a parking structure column retrofitted with carbon fibre reinforced composites. Constr. Build. Mater. 2000, 14, 63-71. [CrossRef]

13. Galal, K.; Arafa, A.; Ghobarah, A. Retrofit of RC square short columns. Eng. Struct. 2005, 27, 801-813. [CrossRef] 
14. Del Zoppo, M.; Di Ludovico, M.; Balsamo, A.; Prota, A. Comparative analysis of existing RC columns jacketed with CFRP or FRCC. Polymers 2018, 10, 361. [CrossRef] [PubMed]

15. Chang, C.; Kim, S.J.; Park, D.; Choi, S. Experimental investigation of reinforced concrete columns retrofitted with polyester sheet. Earthq. Struct. 2014, 6, 237-250. [CrossRef]

16. Napoli, A.; Realfonzo, R. RC columns strengthened with novel CFRP systems: An experimental study. Polymers 2015, 7, 2044-2060. [CrossRef]

17. Lee, H.S.; Kage, T.; Noguchi, T.; Tomosawa, F. An experimental study on the retrofitting effects of reinforced concrete columns damaged by rebar corrosion strengthened with carbon fibre sheets. Cem. Concr. Res. 2003, 33, 563-570. [CrossRef]

18. Mahmoud, F.B.; Hatem, M.M.; Sherif, A.M. Behavior of reinforced concrete columns strengthened by steel jacket. HBRC J. 2015, 11, 201-212. [CrossRef]

19. Tayeh, B.A.; Abu Naja, M.; Shihada, S.; Arafa, M. Repairing and strengthening of damaged RC columns using thin concrete jacketing. Adv. Civil Eng. 2019, 2019. [CrossRef]

20. Araujo, C.V.D.S.; Silva, R.J.C. Experimental and analytical analysis of reinforced concrete columns strengthened with CFRP. J. Build. Pathol. Rehabilit. 2016, 1, 4. [CrossRef]

21. Campione, G.; Fossetti, M.; Giacchino, C.; Minafo, G. RC columns externally strengthened with RC jackets. Mater. Struct. 2014, 47, 1715-1728. [CrossRef]

22. Julio, E.S.; Branco, F.; Silva, V.D. Structural rehabilitation of columns with reinforced concrete jacketing. Prog. Struct. Eng. Mater. 2003, 5, 29-37. [CrossRef]

23. Campione, G. Load carrying capacity of RC compressed columns strengthened with steel angles and strips. Eng. Struct. 2012, 40, 457-465. [CrossRef]

24. Jose, M.A.; Salvador, I.; Francisco, J.P.; Ester, G.; Pedro, A.C. Axially loaded RC columns strengthened by steel caging. Finite element modeling. Constr. Build. Mater. 2009, 23, 2265-2276. [CrossRef]

25. Eunsoo, C.; Young, S.C.; Joonam, P.; Baik, S.C. Behavior of reinforced concrete columns confined by new steel-jacketing method. ACI Struct. J. 2010, 107, 654-662.

26. Ester, G.; Jose, M.A.; Salvador, I.; Pedro, A.C. Influence of strips configuration on the behaviour of axially loaded RC columns strengthened by steel angles and strips. Mater. Des. 2009, 30, 4103-4111. [CrossRef]

27. Vrettos, I.; Kefala, E.; Triantafillou, T.C. Innovative flexural strengthening of reinforced concrete columns using carbon-fibre anchors. ACI Struct. J. 2013, 110, 63-70.

28. Kotynia, R.; Baky, H.A.; Neale, K.W.; Ebead, U.A. Flexural strengthening of RC beams with externally bonded CFRP systems: Test results and 3D nonlinear FE analysis. J. Compos. Construct. 2008, 12, 190-201. [CrossRef]

29. Ye, L.P.; Yue, Q.R.; Zhao, S.H.; Li, Q.W. Shear strength of reinforced concrete columns strengthened with carbon-fibre-reinforced plastic sheet. J. Struct. Eng. 2002, 128, 1527-1534. [CrossRef]

30. Sause, R.; Harries, K.A.; Walkup, S.L.; Pessiki, S.; Ricles, J.M. Flexural behavior of concrete columns retrofitted with carbon fibre-reinforced polymer jackets. ACI Struct. J. 2004, 101, 708-716.

31. Bournas, D.A.; Triantafillou, T.C. Flexural strengthening of reinforced concrete columns with near-surface-mounted FRP or stainless steel. ACI Struct. J. 2009, 106, 495-505.

32. Sarafraz, M.E.; Danesh, F. New technique for flexural strengthening of RC columns with NSM FRP bars. Mag. Concr. Res. 2012, 64, 151-161. [CrossRef]

33. Rodrigues, H.; Furtado, A.; Arede, A.; Vila-Pouca, N.; Varum, H. Experimental study of repaired RC columns subjected to uniaxial and biaxial horizontal loading and variable axial load with longitudinal reinforcement welded steel bars solutions. Eng. Struct. 2018, 155, 371-386. [CrossRef]

34. Wu, Y.F.; Griffith, M.C.; Oehlers, D.J. Improving the strength and ductility of rectangular reinforced concrete columns through composite partial interaction: Tests. J. Struct. Eng. 2003, 129, 1183-1190. [CrossRef]

35. Pudjisuryadi, P.; Tavio, T.; Suprobo, P. Performance of square reinforced concrete columns externally confined by steel angle collars under combined axial and lateral load. Proc. Eng. 2015, 125, 1043-1049. [CrossRef]

36. Paultre, P.; Boucher-Trudeau, M.; Eid, R.; Roy, N. Behavior of circular reinforced-concrete columns confined with carbon fibre-reinforced polymers under cyclic flexure and constant axial load. J. Compos. Constr. 2016, 20. [CrossRef]

37. Rodrigues, H.; Furtado, A.; Arede, A. Experimental evaluation of energy dissipation and viscous damping of repaired and strengthened RC columns with CFRP jacketing under biaxial load. Eng. Struct. 2017, 145, 162-175. [CrossRef] 
38. Montuori, R.; Piluso, V.; Tisi, A. Ultimate behaviour of FRP wrapped sections under axial force and bending: Influence of stress-strain confinement model. Compos. Part B: Eng. 2013, 54, 85-96. [CrossRef]

39. Raza, S.; Khan, M.K.I.; Menegon, S.J.; Tsang, H.H.; Wilson, J.L. Strengthening and repair of reinforced concrete columns by jacketing: State-of-the-art review. Sustainability 2019, 11, 3208. [CrossRef]

40. Sayed, A.M.; Diab, H.M. Modeling of the axial load capacity of RC columns strengthened with steel jacketing under preloading based on FE simulation. Model. Simul. Eng. 2019, 3, 1-8. [CrossRef]

41. Martin, V.; Miroslav, B. Strengthening under load: The effect of preload magnitudes. Proc. Eng. 2016, 161, 343-348. [CrossRef]

42. Martin, V.; Miroslav, B. Strengthening under load: Numerical study of flexural buckling of columns. Proc. Eng. 2017, 190, 118-125. [CrossRef]

43. ACICommittee 318. Building Code Requirement for Structural Concrete (ACI 318-14) and Commentary; Farmington Hills American Concrete Institute: Farmington Hills, MI, USA, 2014.

44. Eurocode 4-ENV 1994-1-1. Design of Composite Steel and Concrete Structures, Part 1-1: General Rules and Rules for Buildings; Thomas Telford BSI: London, UK, 2004.

45. Takeuti, A.R.; Hanai, J.B.; Mirmiran, A. Preloaded RC columns strengthened with high-strength concrete jackets under uniaxial compression. Mater. Struct. 2008, 41, 1251-1262. [CrossRef]

(C) 2020 by the authors. Licensee MDPI, Basel, Switzerland. This article is an open access article distributed under the terms and conditions of the Creative Commons Attribution (CC BY) license (http://creativecommons.org/licenses/by/4.0/). 